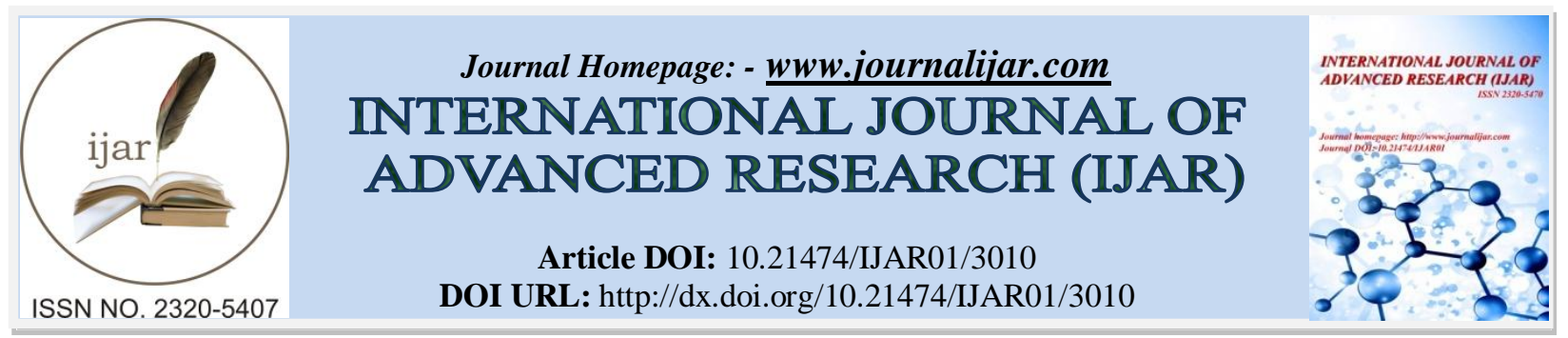

RESEARCH ARTICLE

\title{
TRANSPIRATION DYNAMICS OF PEPPER (CAPSICUM CAPSAULARIS) IN RESPONSE TO ATMOSPHERIC DROUGHT AND SOIL TYPE UNDER SEVERAL VAPOUR PRESSURE DEFICIT (VPD) LEVELS.
}

Md Rais Uddin Rashed.

Agricultural Sciences in the Tropics and SubTropics, University of Hohenheim, Stuttgart, Germany.

\section{Manuscript Info}

Manuscript History

Received: 29 November 2016

Final Accepted: 27 December 2016

Published: January 2017

Key words:-

Vapour pressure deficit, Transpiration rate, Water-use efficiency, Days after sowing, Water holding capacity

\begin{abstract}
Vapour pressure deficit (VPD) is considered as an important environmental factor that affect transpiration rate (TR) in plants. In this study, transpiration rate were observed in Pepper (Capsicum capsaularis) in 3 different soil conditions (organic, sand and mineral) subjected to low (0.10-1.5) and high VPD (2.50-3.90). The highest transpiration rate noted in mineral soil (2.08) but organic one showed more exponential results under high VPD (3.29), comparing lower leaf area to other soil conditions. The lowest TR indicated in sands $(0.17)$ with lower VPD level and large leaf area. The results showed that sand has the lowest transpiration rate and organic soil has the highest transpiration rate. Adding more substrate will be better to compare the transpiration
\end{abstract}

Copy Right, IJAR, 2016,. All rights reserved.

\section{Introduction:-}

Plants lose a copious amount of water by transpiration. Plants take up and transpire a great deal of water by their rooting system. The speed and amount of water moving from the root to shoot in turn determine the concentration of solutes arriving at the shoot (Markhart and Smith 1990).

VPD is a good indicator of plant stress, brought about by either excessive transpiration of water (high VPD values) or the inability to transpire adequately (low VPD values). VPD alone does not provide a perfect model of crop water stress. However, if the measurements of VPD calculation are taken in a manner that provides an accurate representation of the current crop conditions, it could be used to influence key environmental control management decisions. Saturated vapour pressure are increasing exponentially with increasing temperature to impact on plant growth (Sinclair et al., 2007). Temperature and vapor pressure deficit (VPD) effects on plant growth are almost always confounded in experiments because VPD is increasing with the decreasing temperature. Increasing VPD rate raise up the atmospheric demand, and consequently higher plant transpiration (Sinclair et al., 2007). A large number of researchers showed that higher leaf to air, VPD decreased stomatal conductance (Bunce 2006, Lopez-Berenger et al., 2006). Stomatal closure limits the transpiration rate and sometimes a decrease at high VPD (Oren et al., 2001). Therefore, stomatal closure restricts the corresponding decrease in plant water potential and prevents excessive water loss.

Different types of soil play a distinguishing role in the plant's ability to extract water. It is noted that water holding capacity depends on soil texture and the effects of soil organic matter are strongest in more sandy soils (Hudson

Corresponding Author:- Md Rais Uddin Rashed.

Address:- Agricultural Sciences in the Tropics and SubTropics, University of Hohenheim, Stuttgart, Germany. 
1994; Minasny et al. 1999; Rawls et al. 2003). Texture, structure and porosity influences the movement and retention of water in the soil, which subsequently aff ects the plants transpiration (Moyano et al. 2013).

The original intent of this experiment was to study the effect of transpiration rate, as manipulated by several vapor pressure deficit levels in combination with different soil conditions. Pepper (C3) showed substantial differences in their rate and sensitivity to the VPD and limitations in transpiration rate at high VPD. Most of the studies have been conducted in a specific growth phase of the crop, while there is little information on transpiration rate over the plants ontogeny but these studies has been conducted for checking the soil effects on plant transpiration rate.

\section{Objectives:-}

To measure the effect of transpiration rate on Pepper (C3) plants in response to changes the atmospheric vapour pressure deficit.

\section{Hypothesis:-}

The hypotheses are

Soil has the effects on transpiration rate

\section{Materials and Methods:-}

The experiment was carried out during the summer season under greenhouse conditions $\left(22-35^{\circ} \mathrm{C}\right.$; light: dark $=$ 16:8 hours).

\section{Plant material:-}

Pepper (Capsicum capsaularis) seeds were used to getting seedlings. This was needed at least 6-8 hours of sunlight per day. Support each pepper plant with a stake, to help bear the weight of the broad leaf and fruits.

\section{Plants growing strategy:-}

The whole experiment was split into three sub divisions

1. Pepper plants were raised in three (organic, mineral and sand) different conditions in controlled environments.

2. Transpiration rates were measured in the climate chamber and biomass harvested.

Table 1:- Species and their photosynthetic metabolism, life form, substrate and corresponding family of Pepper plant

\begin{tabular}{|c|c|c|c|c|}
\hline Species & $\begin{array}{c}\text { Photosynthetic } \\
\text { metabolism }\end{array}$ & Life form & Substrate & Family \\
\hline Capsicum capsaularis & C3 & Perenial Dicotyledonous & $\begin{array}{c}\text { Organic soil } \\
\text { Sand } \\
\text { Mineral soil }\end{array}$ & Piperaceae \\
\hline
\end{tabular}

\section{Soil properties:-}

Pepper was raised in three different (organic, mineral and sand) conditions in controlled environment. Each soil has different properties (Table 1)

Table 1:- Guinea grass in different substrates

\begin{tabular}{|c|c|l|}
\hline \multicolumn{1}{|c|}{ Species } & \multicolumn{1}{|c|}{ Soil type } & \multicolumn{1}{c|}{ Soils description } \\
\hline \multirow{3}{*}{ Capsicum capsaularis } & Organic soil & $\begin{array}{l}\text { Its contain more than 20\% organic carbon } \\
\text { Fine textured soil } \\
\text { High water retention capacity }\end{array}$ \\
\cline { 2 - 3 } & Sand & $\begin{array}{l}\text { less nutrient and Low water holding capacity } \\
\text { large particles (2.0 mm -0.05 mm) }\end{array}$ \\
\cline { 2 - 3 } & Mineral soil & $\begin{array}{l}\text { Derived from minerals or rocks and containing little } \\
\text { humus or organic matter } \\
\text { Less than 20\% of carbon contend }\end{array}$ \\
\hline
\end{tabular}




\section{Seedling were raising in three different soil conditions:-}

Three seeds of pepper were placed in three (mineral, sand and organic) different soil conditions in each and every pot. One week after germination, the pots were thinned to single germinated seedling. (Figure 1).

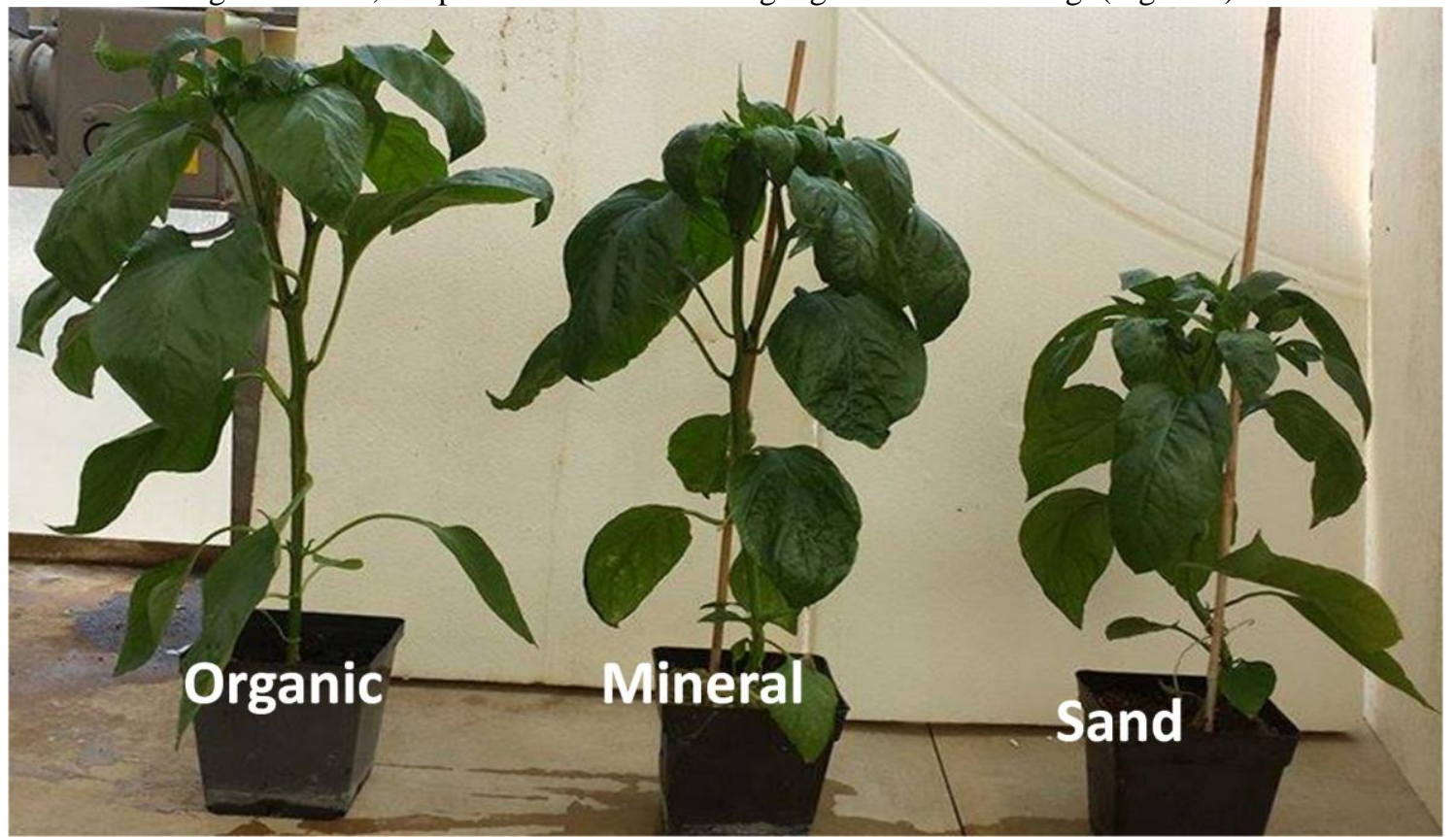

Fig 1:- Pepper (C3) plants are growing in three different soil conditions (organic, mineral and sand respectively).

\section{Technical set-up for climate chamber:-}

The plant transpiration rate was measured in a climate chamber $(80 \times 80 \times 100 \mathrm{~cm})$ with PVC transparent side and top elements. LED light was installed $15 \mathrm{~cm}$ away from the top of the climate chamber for providing photosynthetic photon flux (PPF) at $600 \mu \mathrm{mol} \mathrm{m} \mathrm{s}^{-1}$ at the bottom and $1200 \mu \mathrm{mol} \mathrm{m} \mathrm{m}^{-2} \mathrm{~s}^{-1}$ near the top. Uninterrupted air flow through the VPD chamber excluded the possibility of carbon dioxide deficit in the chamber. The temperature and the relative humidity were recorded every minute for calculating the accurate atmospheric VPD by using Tinytag data loggers (Type-TV4505, Gemini Data Loggers., UK). Four individual balances (KERN KB 2400-2N d=0.01g, with a maximum load of 2400g) arranged symmetrically in order to maintain equal light conditions which are connected to a PC for every minute weight information with GrassLog software version 0.1. Four box fans are installed on the top of the chamber for mixing the inside air by continuously adjustable intensity.

A desiccant dehumidifier (Consorb DC-10, Seibu Giken, Sweden) was used to generate dry air at a flow rate of max. $190 \mathrm{~m}^{3} / \mathrm{h}$. The air flow at $60 \mathrm{~m}^{3} / \mathrm{h}$ was simultaneously used to counterbalance temperature losses of the wet air produced by ultrasonic nebulizers (Fogstar 100, Seliger GmbH, Germany). Both air streams were saturated before entering the chamber from a side entrance. The speed of each air stream was adjustable with throttle flaps placed inside PVC tubes before mixing.

The actual atmospheric VPD was measured by calculating the recorded every 60 seconds relative humidity and temperature. Different humidity levels were reached by adjusting throttle flaps of wet and dry airstreams while targeting four VPD levels between 0.40 and 3.80 . 


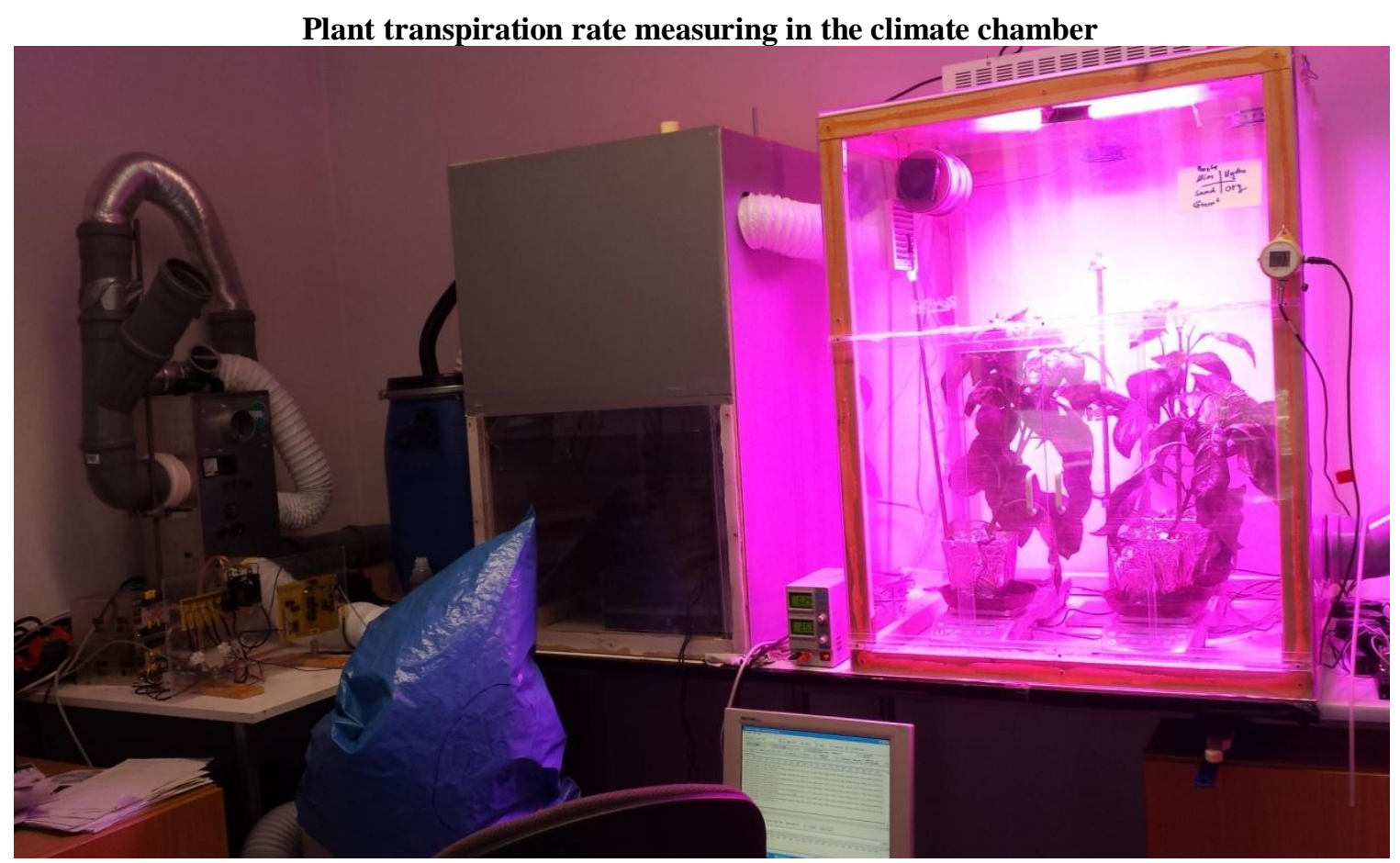

Figure 2:- Transpiration rate measuring in climate chamber

Figure 2. Showing the transpiration rate measurement in climate chamber. The pot was covered with aluminum foil to reduce evaporation. VPD was maintained approximately $0.5 \mathrm{kPa}$ and increased stepwise to almost $4.0 \mathrm{kPa}$. After the equilibrium condition in the chamber, the entire unit of plants and pot were weighed on a balance. Plant transpiration rates were recorded based on the mass loss. Four humidity levels in the chamber were established by adjusting the humid and dry air. Transpiration rate were started to measure from low VPD to higher VPD. Transpiration rates were recorded over 20 minutes for each VPD levels with an interval of 5 minutes for adjusting VPD until the starting of the higher VPD levels. The measurements for each replicate consisted of four VPD levels for around 2 hours in total.

Determination of transpiration rate and dry biomass:-

After measuring the transpiration rates, plants were clipped at the stem base and separated into shoot and root. The total leaf area was measured in green house by using LI-3100 area meter. Every pot was immersed in water to remove sand, soil and inert materials. Roots were further washed, cleaned and sealed separately in leveled paper bags. Whole plant tissues were dried in an oven at $70^{\circ} \mathrm{C}$ for 48 hours to get the constant weight.

\section{Statistical Calculation:-}

Transpiration rate calculation:-

Plant transpiration rates (TR) were calculated per unit of leaf area $\left(\mathrm{mmol} \mathrm{H}_{2} \mathrm{Om}^{-2} \mathrm{~s}^{-1}\right)$, based on their pot weight changing in every minute's interval.

$\mathrm{TR}=\{(\mathrm{W} 0-\mathrm{W} 1) / 18\} /$ Time $\times$ Leaf Area

$\mathrm{W} 0=$ the initial weight

$\mathrm{W} 1=$ weight after 60 seconds

VPD were calculated by using recorded temperature and relative humidity. The data were analyzed by plotting TR against VPD using Software package SAS.

\section{Root-Shoot ratio calculation:-}

Root dry weight $(\mathrm{g})$ was divided by Shoot dry weight $(\mathrm{g})$ in each and every replication.

$$
\text { Root }- \text { Shoot ratio }=\frac{\text { Root dry weight }(\mathrm{g})}{\text { Shoot dry weight }(\mathrm{g})}
$$




\section{Normalizing transpiration rate to VPD:-}

VPD in the chamber were manipulated by manually through adjusting the relative humidity while keeping the temperature constant. Therefore, the exact VPD couldn't be fixed at exactly $0.5,1.90,2.90,3.70 \mathrm{KPa}$. All the TR values were plotted against their respective VPD to produce regression line compare with TR and VPD.

\section{Results:-}

Root-Shoot ratio:-

Table 3:- Root-Shoot ratio (root dry weight (g) / shoot dry weight (g)) in three soil conditions respectively).

\begin{tabular}{|c|c|}
\hline Soil condition & Root/Shoot \\
\hline Organic & 0.3053 \\
\hline Mineral & $\mathbf{0 . 4 3 6 5}$ \\
\hline Sand & 0.2798 \\
\hline
\end{tabular}

Table 03 showed that root-shoot ratio was higher in mineral soil and lower in sand. In organic condition the ratio is in between two of them. Root-shoot ration is higher in mineral and transpiration rate also higher but less exponential then organic condition with their increasing VPD.

\section{Transpiration rate measurement in different soil condition:-}

Transpiration rate were measured in different soil condition in the climate chamber and three exponential lines were indicated different transpiration rate in the figure 03,04 and 05.
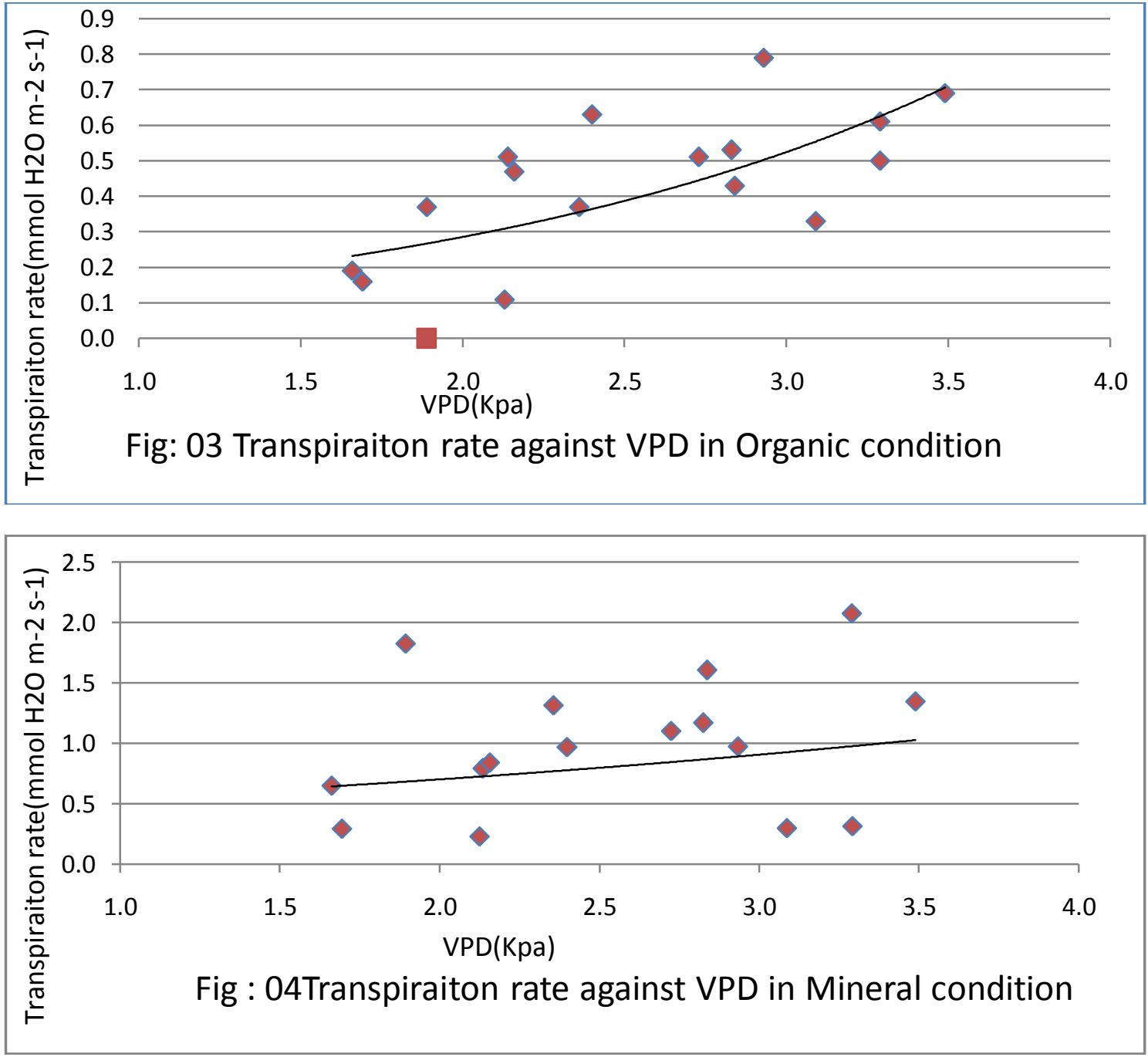


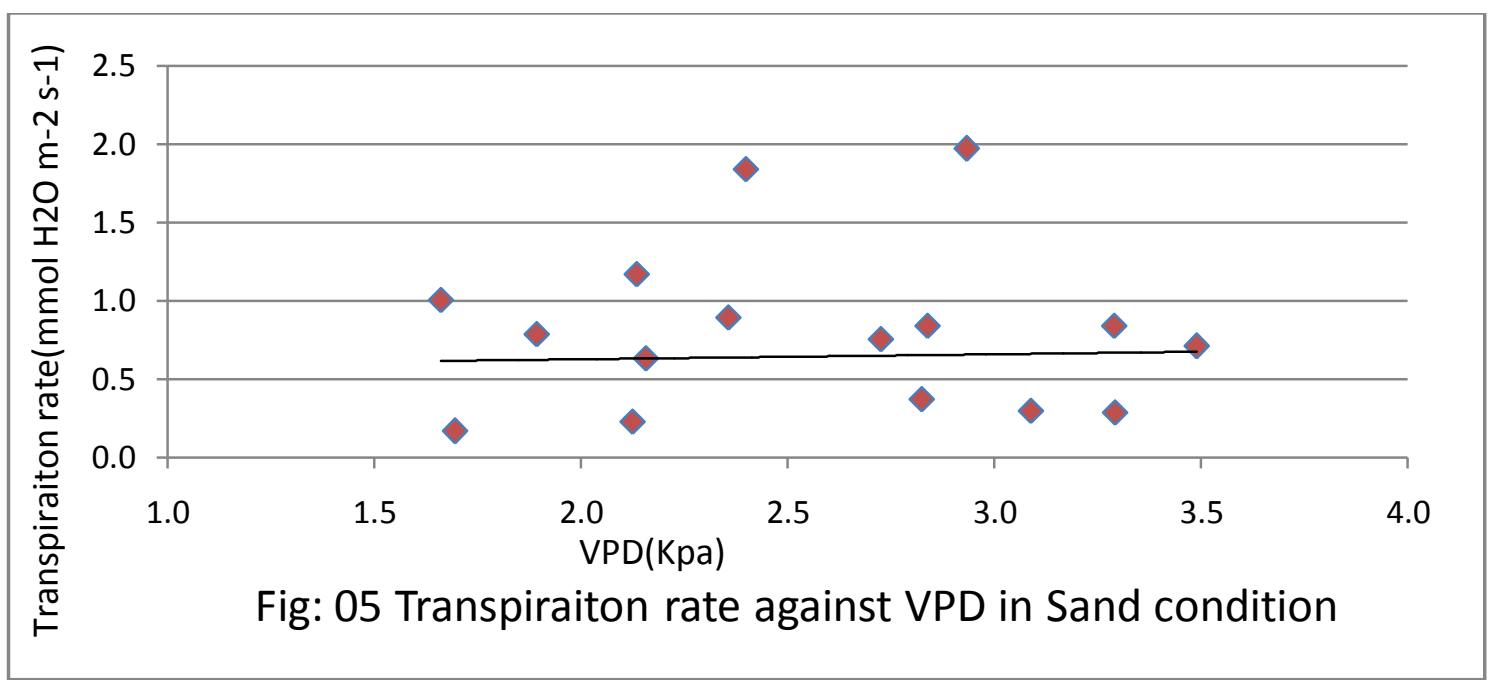

Figure 03 showed that, transpiration rate were gradually increasing with their increasing VPD Exponential line of transpiration rate showed organic condition that, it's increasing with the increasing VPD. Figure 04 indicated that, transpiration rate in mineral soil were increasing but the line were less exponential compare to the organic condition. In figure 05 showed that, transpiration rate were vibrating the same way with their increasing VPD.

Table 4:- Analysis of variance

\begin{tabular}{|c|c|c|}
\hline Analysis of variance & VPD & TR \\
\hline Organic & 2.558 & 0.4502 \\
\hline Mineral & 2.557 & 0.9860 \\
\hline Sand & 2.557 & 0.7997 \\
\hline P value at 0.05 & 0.002 & 0.687 \\
\hline Sig. Level & NS & NS \\
\hline CV (\%) & 0.05 & 53.29 \\
\hline
\end{tabular}

Table 04 showed that, transpiration rate of each and every substrate is not significant with their respective VPD. The organic one indicated more transpiration compare to the other soil condition.

\section{Discussion:-}

\section{Biomass measurement in relation to transpiration rate:-}

The rate of water supply to the plant shoot is dependent on both the conductance of water in the soil and in the roots (Hogg and Hurdle, 1997; Meiner and Grantz, 1990). In that case, the organic soil has the huge possibility for water, root conductance and transpired more water than the mineral soil followed by sand. The fine textured soil has the more ability to preserve and continuous water supply around the root zones compare to the sandy soil.

\section{Root-Shoot ratio:-}

The rate of transpiration tends to increase with higher root-shoot ratio (Devlin, 1975). He also mentioned that it is expected that a plant with a higher root: shoot value will tend to transpire faster than another plant with a lower root to shoot. In this experiment it's observed that, the root-shoot ratio was higher in mineral soil. Higher leaf area against root volume compare to the others could be the reason (Table 03).

\section{Soil properties in terms of transpiration rate:-}

Soil texture highly influences water infiltration, $\mathrm{pH}$, permeability and water holding capacity. Soil texture refers to the composition of the soil in terms of the proportion of small, medium and large particles (clay, silt and sand respectively) in a specific soil mass. Brady (1990) mentioned that sandy soils have low porosity and the movement of air and water is rapid. Soil porosity refers to the space between soil particles, which consists of various amounts of water and air. A fine soil has smaller but more numerous pores than a coarse soil. A coarse soil has bigger particles than a fine soil, but it has less porosity or overall pore space. 
Smettem and Collis-George (1985) reported that a single continuous pore of $0.3 \mathrm{~mm}$ diameter can conduct more water than the rest of a $100 \mathrm{~mm}$ diameter sample. Water can be held tighter in small pores than in large ones, so fine soils can hold more water than coarse soils.

In that case, available water was higher in organic and mineral soil and transpires more water than the sandy soils (appendix 03). Naiman et al., (1994) also mentioned that higher levels of organic matter result in a greater number of cation exchange sites which tend to decrease the $\mathrm{pH}$. He also added sandy soils with a low CEC are generally unsuited for septic systems since they have the little adsorptive ability and there is potential for groundwater. The main effect of soil $\mathrm{pH}$ is on the availability of plants nutrients which have the specific preference range of soil $\mathrm{pH}$. So $\mathrm{pH}$ could be varied and it might have the effects on nutrients absorption, even extra nutrients was supplied in sand and mineral growth medium for equal plant growth but the effects still unclear.

In this study, transpiration difference was isolated by comparing similar size individual pot weight in each plant. Results showed that organic substrate transpire much of water by generating the shoot biomass. (Fig: 03).

Measurement of 55 days old Pepper (C4) plant showed large leaf area in mineral soil condition but the effect of less transpiration rate. Plants may sense different soil condition and hence send inhibitory signals to the shoots which harden the plants against the consequences of a degrading environment, especially if the plants water supply is at risk. Transpiration rate can be interpreted as anticipated rates to the soil becoming too dry. Since different substrates condition varying degree of the inhibitory signals may affect and different stomatal conductance, cell expansion, cell division and the rate of leaf appearance.

\section{Acknowledgment:-}

I am very grateful to all members of the Institute of Plant Production and Agro-ecology in the Tropics and SubTropics, University of Hohenheim, Stuttgart, Germany.

\section{Conclusion:-}

In the present study, its shows different rate of foliar transpiration over its ontogeny under lowers to higher VPD levels. Although little or no change in leaf appearance was shown in this study, differences were observed in overall plant leaf area under low and high VPD. But the results showed that leaf area expansion is a key difference to high VPD. Under high VPD, higher TR was associated with lower leaf area expansion rates as shown in the results for Pepper (C3) plant. Including by more substrates and growth stages should be the preference for further research. Checking the rewetting data could be the possible way to know plant recovering and soil texture.

Including by more substrates and growth stages would be the preference for further research. Checking the rewetting data could be the possible way to know plant recovering. Tying a small around among the all exposed leaves would be the way in order to obtain the exact amount transpired from the water source into the atmosphere. This will be able to provide more details on the exact time and amount of water was transpired.

\section{References:-}

1. Moyano, F., Manzoni, S. and Chenu, C., 2013. Responses of soil heterotrophic respiration to moisture availability: An exploration of processes and models (review). Soil Biology and Biochemistry 59, 72-85.

2. Minasny, B., McBratney, A.B. and Bristow, K.L.,1999. Comparison of different approaches to the development of pedotransfer functions for water- retention curves. Geoderma 93, $225-53$.

3. Rawls, W.J., Pachepsky, Y.A., Ritchie, J.C., Sobecki, T.M. and Bloodworth, H., 2003. Effect of organic carbon on soil water retention. Geoderma. 116, $61-76$.

4. Hudson, B.D., 1994. Soil organic matter and available water capacity. Journal of Soil and Water Conservation. 49, $1898-194$.

5. Adams, H.D., Guardiola-Claramonte, M., Barron-Gafford, G.A., Villegas, J.C., $\quad$ Breshears, D.D., Zou, C.B., Troch, P.A., Huxman, T.E. 2009. Temperature sensitivity of drought-induced tree mortality portends increased regional die-off under global-change-type drought. Proceedings of the National Academy of Science, USA 106: 7063-7066.

6. Bouchabké, O., Tardieu, F., Simonneau, T,. 2006. Leaf growth and turgor in growing cells of maize (Zeamays L.) respond to evaporative demand under moderate irrigation but not in water-saturated soil. Plant, Cell and Environment 29:1138-1148. 
7. Bunce, J.A., 2006. How do leaf hydraulics limit stomatal conductance at high water vapour pressure deficits? Plant, Cell and Environment 29:1644- 1650.

8. Clifton-Brown, J.C. and Jones, M.B., 1999. Alteration of TR, by changing air vapour pressure deficit, influences leaf extension rate transiently in Miscanthus. Journal of Experimental Botany 50: 1393-1401.

9. De Boodt, M. and Verdonck, O., 1972. The physical properties of the substrates in horticulture. In: Penningsfeld, F. (Ed.), Peat in Horticulture. Acta Horticulture. 26: 37-44.

10. Ehlert, C., Maurel, C., Tardieu, F.O., Simonneau, T., 2009. Aquaporin-mediated reduction in maize root hydraulic conductivity impacts cell turgor and leaf elongation even without changing transpiration. Plant Physiology 150: 1093-1104.

11. Fletcher, A.L., Sinclair, T.R., Allen Jr, L.H., 2007. Transpiration rates to vapor pressure deficit in wellwatered slow wilting and commercial soybean. Environmental and Experimental Botany 61: 145-151.

12. Hirasawa, T. and Hsiao, T.C., 1999. Some characteristics of reduced leaf photo synthesis at midday in maize growing in the field. Field Crop Resources 62: 53-62.

13. Lopez-Berenguer, C., Garcia-Viguera, C., Carvajal, M., 2006. Are Root Hydraulic Conductivity rate to Salainity Controlled by Aquaporins in Broccoli Plants? Plant and Soil 279:13-23.

14. Markhart, A.H. and Smit, B. 1990. Measurement of root hydraulic conductance. Hort Science 25:282-287.

15. Meyers, R.J.K., Foale, M.A., Done, A.A., 1984. Rate of grain sorghum to varying irrigation frequency in the Ord irrigation area. II. Evapotranspiration water-use efficiency. Australian Journal of Agricultural Research 35: $31-42$.

16. Monteith,J.L.,1993.The exchange of water and carbon by crops in a Mediterranean climate. Irrigation Science 14:85-91.

17. Munns, R., Passioura, J.B., Guo, J., Chazen, O., Cramer, G.R., 2000. Water relations and leaf expansion: importance of time scale. Journal of Experimental Botany 51:1495-1504.

18. Ocheltree, T.W., Nippert, J.B. and Prasad, P.V.V., 2013. Stomatal rate to change in vapour deficit reflect tissue specific difference in hydraulic conductance Plant, Cell and Environment .1-8.

19. Oren, R., Sperry, J.S., Ewers, B.E., Pataki, D.E., Philips, N. and Megonigal, J.P., 2001. Sensitivity of mean canopy stomatal conductance to vapour pressure deficit in a flooded Taxodium distichum L. forest: hydraulic and non-hydraulic effects. Oecologia 126:21-29.

20. Peterman, W., Waring, R.H., Seager, T., Pollack, W.L., 2012. Soil properties affect pinyon pine-juniper rateb to drought. Ecohydrology. doi:10.1002/eco.1284.

21. Sinclair, T., Fiscus, E., Wherley, B., Durham, M., Rufty, T., 2007. Atmospheric vapor deficit is critical in predicting growth rate of "cool-season" grass Festuca arundiacea to temperature change. Planta 227. 273276.

22. Sinclair, T.R., Hammer, G.L., van Oosterom, E.J., 2005. Potential yield and water-use efficiency benefits in sorghum from limited maximum transpiration rate. Functional Plant Biology 32: 945-952.

23. Tardieu, F. and Tuberosa, R., 2010. Dissection and modelling of abiotic stress tolerance in plants. Current Opinion in Plant Biology 13: 206-212.

24. Welcker, C., Boussuge,B., Bencivenni, C., Ribaut, J.M., Tardieu, F., 2007. Are source and sink strengths genetically linked in maize plants subjected to water deficit? A QTL study of the rates of leaf growth and of Anthesis-Silking Interval to water deficit. Journal of Experimental Botany 58: 339-349.

25. Wherley, B.G. and Sinclair, T.R., 2009. Differential sensitivity of C3 and C4 turf grass species to increasing atmospheric vapour pressure deficit. Environmental and Experimental Botany 67:372-376. 


\section{Appendix 01:-}

Nutrient solution preparation:-

A number of chemical with their exact amount were added for stock solution

Table 2:- Nutrient solution preparations for hydroponic system

\begin{tabular}{|c|c|c|c|c|c|c|c|c|}
\hline label & Chem. substance & $\begin{array}{l}\text { Conc. } \\
\text { stock }\end{array}$ & $\begin{array}{c}\text { Molecular } \\
\text { weight }\end{array}$ & $\begin{array}{l}\text { Sample } \\
\text { weight } \\
\text { per } \\
\text { 1L stock }\end{array}$ & $\begin{array}{c}\text { Sample } \\
\text { weight per } \\
\text { 2L stock }\end{array}$ & $\begin{array}{l}\text { Final } \\
\text { conc. }\end{array}$ & $\begin{array}{l}\text { Dil. } \\
\text { factor }\end{array}$ & $\begin{array}{c}\text { ml of } \\
\text { stock for } \\
\text { 1L final } \\
\text { solution }\end{array}$ \\
\hline A & $\begin{array}{c}\mathrm{K}_{2} \mathrm{So}_{4} \\
\mathrm{KCL} \\
\end{array}$ & $\begin{array}{l}0.35 \mathrm{M} \\
0.05 \mathrm{M} \\
\end{array}$ & $\begin{array}{l}174.26 \mathrm{~g} \\
74.55 \mathrm{~g} \\
\end{array}$ & $\begin{array}{c}60.99 \mathrm{~g} \\
3.73 \mathrm{~g} \\
\end{array}$ & $\begin{array}{c}121.98 \mathrm{~g} \\
7.45 \mathrm{~g}\end{array}$ & $\begin{array}{c}0.7 \mathrm{mM} \\
0.1 \mathrm{mM} \\
\end{array}$ & 500 & $\begin{array}{l}2 \\
2 \\
\end{array}$ \\
\hline $\mathrm{B}$ & $\mathrm{KH}_{2} \mathrm{PO}_{4}$ & $0.1 \mathrm{M}$ & $136.09 \mathrm{~g}$ & $13.61 \mathrm{~g}$ & $27.22 \mathrm{~g}$ & $0.1 \mathrm{mM}$ & 1000 & 1 \\
\hline $\mathrm{C}$ & $\mathrm{MgSO}_{4 *} 7 \mathrm{H}_{2} \mathrm{O}$ & $0.5 \mathrm{M}$ & $246.48 \mathrm{~g}$ & $123.24 \mathrm{~g}$ & $246.48 \mathrm{~g}$ & $0.5 \mathrm{mM}$ & 1000 & 1 \\
\hline $\mathrm{D}$ & $\mathrm{Ca}\left(\mathrm{NO}_{3}\right)_{2} * 4 \mathrm{H}_{2} \mathrm{O}$ & $1 \mathrm{M}$ & $236.15 \mathrm{~g}$ & $\begin{array}{l}236.15 \mathrm{~g} \\
472.30 \mathrm{~g}\end{array}$ & $472.30 \mathrm{~g}$ & $2.0 \mathrm{mM}$ & $\begin{array}{c}500 \\
1000 \\
\end{array}$ & $\begin{array}{l}2 \\
1 \\
\end{array}$ \\
\hline $\mathrm{E}$ & $\begin{array}{c}\mathrm{MnSO}_{4} * \mathrm{H}_{2} \mathrm{O} \\
\mathrm{ZnSO}_{4} * 7 \mathrm{H}_{2} \mathrm{O} \\
\mathrm{CuSO}_{4} \text { or } \\
\mathrm{CuSO}_{4} * 5 \mathrm{H}_{2} \mathrm{O} \\
\left(\mathrm{NH}_{4}\right)_{6} \mathrm{Mo}_{7} \mathrm{O}_{24} * 4 \mathrm{H}_{2} \mathrm{O}\end{array}$ & $\begin{array}{c}0.5 \mathrm{mM} \\
0.1 \mathrm{mM} \\
0.2 \mathrm{mM} \\
0.01 \mathrm{~m} \\
\mathrm{M} \\
\end{array}$ & $\begin{array}{c}169.09 \mathrm{~g} \\
287.54 \mathrm{~g} \\
159.60 \mathrm{~g} \\
249.68 \mathrm{~g} \\
1235.86 \mathrm{~g}\end{array}$ & $\begin{array}{l}84.51 \mathrm{mg} \\
28.75 \mathrm{mg} \\
31.92 \mathrm{mg} \\
49.54 \mathrm{mg} \\
12.36 \mathrm{mg}\end{array}$ & $\begin{array}{l}169.02 \mathrm{mg} \\
57.51 \mathrm{mg} \\
63.87 \mathrm{mg} \\
99.88 \mathrm{mg} \\
24.72 \mathrm{mg}\end{array}$ & $\begin{array}{l}0.5 \mu \mathrm{M} \\
0.1 \mu \mathrm{M} \\
0.2 \mu \mathrm{M} \\
\\
1 * 10 \\
{ }^{-8} \mathrm{M} \\
\end{array}$ & 1000 & 1 \\
\hline $\mathrm{F}$ & $\mathrm{H}_{3} \mathrm{BO}_{3}$ & $10 \mathrm{mM}$ & $61.83 \mathrm{~g}$ & $\begin{array}{l}618.3 \mathrm{mg} \\
309.1 \mathrm{mg}\end{array}$ & $\begin{array}{c}1.237 \mathrm{~g} \\
618.3 \mathrm{mg}\end{array}$ & $\begin{array}{l}10 \mu \mathrm{M} \\
20 \mu \mathrm{M} \\
\end{array}$ & $\begin{array}{c}1000 \\
500 \\
\end{array}$ & $\begin{array}{l}1 \\
2 \\
\end{array}$ \\
\hline G & FeNaEDTA & $50 \mathrm{mM}$ & $367.05 \mathrm{~g}$ & $\begin{array}{l}4.6 \mathrm{~g} \\
5.5 \mathrm{~g} \\
\end{array}$ & $\begin{array}{l}\text { in } 250 \mathrm{ml} \\
\text { in } 300 \mathrm{ml}\end{array}$ & $50 \mu \mathrm{M}$ & 1000 & 1 \\
\hline
\end{tabular}

